\title{
MANFAAT MENGONSUMSI AIR ZAM-ZAM DALAM PERSFEKTIF ISLAM DAN SAINS
}

\author{
Dwi Putri Oktaviani ${ }^{1}$, Agus Fakhruddin ${ }^{2}$ \\ Universitas Pendidikan Indonesia, Universitas Pendidikan Indonesia \\ dwiputrioktaviani@upi.edu,agusfakhruddin@upi.edu
}

\begin{abstract}
Zam-zam water is water that appeared in the period of Prophet Ismail as., Long before the birth of Prophet Muhammad SAW. Zam-zam water has received testimony and direct justification from the Prophet Muhammad as the best water on earth which contains many benefits. Explicitly, the properties of zam-zam water are listed in the hadith, which is considered authentic quality according to scholars. The article examines the existence of zam-zam water from a hadith perspective and a scientific perspective. In the hadith perspective. This article also examines the benefits of Zamzam water, through a scientific approach, zam-zam water will be more deeply researched so that a scientific fact can be found that the substances contained and molecules arranged in zam-zam water is better than other substances or water molecules. . So, the Prophet Muhammad's justification for zam-zam water is proven by the truth of the facts of modern scientific research.
\end{abstract}

Keywords: Zamzam water, science

Meskipun sumber air dunia terbatas, dan sumber yang ada menipis dengan cepat, ada sumber air bernama Zamzam yang menyediakan air bagi milyaran orang. Bagi umat Islam, itu adalah air suci, yang telah memuaskan dahaga orang sejak awal sejarah manusia. Sumber air ini berada di kawasan Mekah, salah satu kota paling suci bagi umat Islam. Kota ini terletak di bagian barat Arab Saudi sekitar $70 \mathrm{~km}$ sebelah selatan kota Jeddah di pesisir Laut Merah. Secara geografis dapat ditemukan pada garis lintang $21^{\circ} 26^{\prime}, 48^{\prime} \mathrm{N}$, garis bujur $39^{\circ} 53^{\prime}, 46^{\prime} \mathrm{BT}$, dengan ketinggian sekitar 1399 kaki di atas permukaan laut. (Al-Gamal, 2008)

Air zam zam sendiri pertama kali muncul saat Nabi Ibrahim bersama istrinya, Siti Hajar dan anaknya yang masih bayi Nabi Ismail sedang ada di perjalanan dan persediaan makanan mereka habis. Nabi Ismail yang masih bayi terus menangis di tempat yang tidak ada seorang pun itu karena kehausan. Melihat anaknya yang terus menangis, Siti Hajar berusaha mencari air dengan berlari dari Bukit Safa ke Bukit Marwah terus menerus. Tercatat Siti Hajar berlari sebanyak 7 kali. Dan inilah yang kemudian menjadi rukun haji saat ini. Setelah itu, atas izin Allah kaki kecil Nabi Ismail menghentak ke tanah dan muncul lah mata air yang 
menyegarkan untuk mereka. Dan itu lah air zam zam yang selalu mengalir dan tidak pernah kering.

Air zamzam merupakan air suci dan air yang terbaik yang ada di permukaan bumi ini. Air zamzam mengandung banyak elemen yaitu ion positif dan ion negatif. Komposisi multiunsur dan hidrokimia air zamzam terdapat sebanyak 34 elemen, diantaranya yaitu, Kalsium (Ca), Magnesium (Mg), Natrium (Na) dan Klorida $(\mathrm{Cl})$ dalam konsentrasi tertinggi. Unsur-unsur Antimon ( $\mathrm{Sb}$ ), Berilium (Be), Bismuth (Bi), Bromin (Br), Kobalt (Co), Iodine (I), dan Molibdenum (Mo) kurang dari 0,01 ppm. Kromium (Cr), Mangan (Mn), dan Titanium (Ti) juga terdeteksi dalam air zamzam. (Naeem, 1983)

Tiap kandungan elemen ini memiliki peranan utama terhadap fungsi vital sel pada tubuh manusia. Melalui artikel ini, akan mencoba menjelaskan manfaat dan khasiat yang terkandung didalam zamzam berdasarkan fakta-fakta ilmiah dan hadis.

\section{METODE}

Dengan bahan yang digunakan, penelitian ini memakai metode kajian pustaka juga metode komparatif. Mulamula akan dibahas khasiat air zam-zam perspektif hadis. Kemudian akan ditinjau pula khasiat air zam-zam berdasarkan sains modern dengan melihat zat-zat yang terkandung pada air zamzam, juga struktur molekul yang tersusun di dalamny, akan dibahas pula hasil penelitian Masaru Emoto, peneliti air asal Jepang, mengenai keajaiban air. Lalu pada akhirnya akan dibuktian kebenaran hadis melalui sains modern dengan mengompromikan khasiat air zam-zam antara perspektif hadis dan sains.

\section{PEMBAHASAN}

\section{Hadis tentang Air Zam-zam}

Hadis-hadis berkenaan dengan air zam-zam adalah sebagai berikut:

1. Ibnu Majah, nomor 3053

Riwayat Ibnu Madjah dalam Sunan Ibnu Majah No indeks 3053 


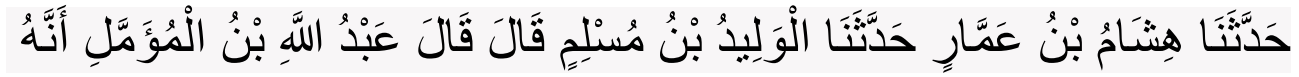

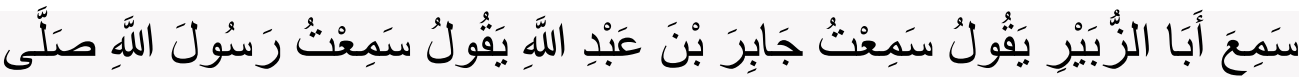

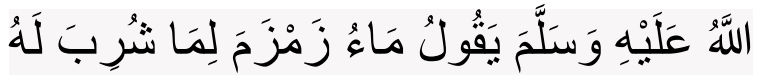

Telah menceritakan kepada kami Hisyam bin Ammar; telah menceritakan kepada kami Al Walid bin Muslim berkata; Abdullah bin Mu`ammal berkata; bahwa ia mendengar Abu Az Zubair berkata; Aku mendengar Jabir bin Abdullah radliallahu 'anhu, ia berkata; Aku mendengar Rasulullah shallallahu 'alaihi wasallam bersabda: 'Air Zam-zam (berkhasiat) sesuai dengan niat (tujuan) diminum (oleh penggunanya).(al-Qazwini, 1995)

2. Musnad Ahmad, nomor 14320

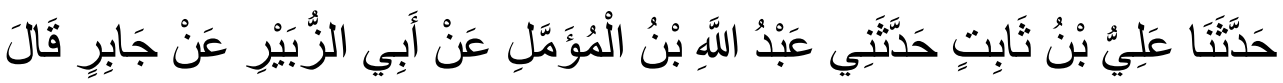

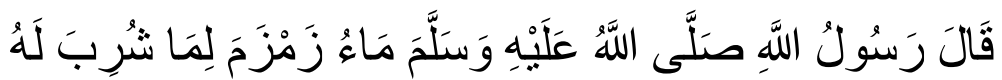

Telah menceritakan kepada kami Ali ibn Thabit, dari Abdullah Ibn Mu'ammal, dari Abu Az Zubair, dari Jabir Ibn Abdullah radliallahu 'anhu, dari Rasulullah shallallahu 'alaihi wasallam bersabda: 'Air Zamzam (berkhasiat) sesuai dengan niat (tujuan) diminum (oleh penggunanya).(Hanbal, 1995)

3. HR. Daru Qutni dan Hakim, Hadits hasan li ghairihi. Kitab Shahih Targhib wa Tarhib, al Albani, 2/19

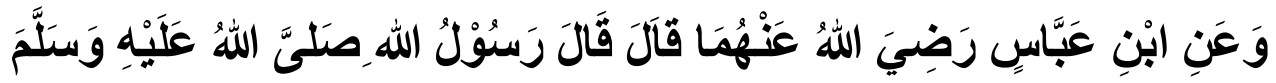

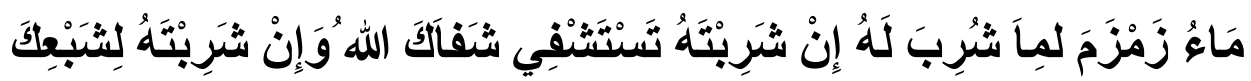

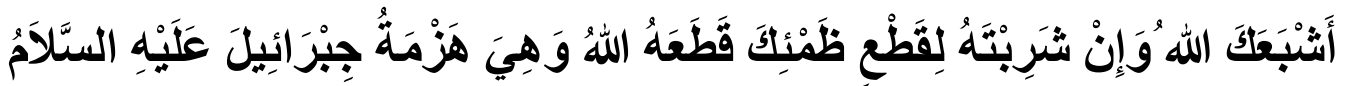

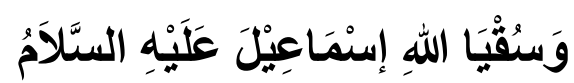

Dari Ibnu 'Abbas Ra., Rasulullah SAW. bersabda: "Air Zam-Zam sesuai dengan niat ketika meminumnya. Bila engkau meminumnya untuk obat, semoga Allah menyembuhkanmu. Bila engkau meminumnya untuk menghilangkan dahaga, semoga Allah menghilangkannya. Air Zam-Zam ialah 
galian Jibril, dan curahan minum dari Allah kepada Ismail." (Ad-Daraqutni, 2004)

\section{Air Zam-zam Perspektif Agama, Hadis}

Manfaat dan keutamaan air zam-zam yang termaktub dalam hadis, diperjelas oleh Said Bakdasy dalam bukunya yang berjudul Fadhl Ma' Zam-zam. Ia menyebutkan dua puluh tiga manfaat dan keutamaan air zam-zam, di antaranya:

1. Air zam-zam merupakan salah satu mata air dari berbagai mata air yang ada di surga.

2. Air zam-zam adalah penghidup kota Mekah.

3. Air zam-zam adalah air terbaik yangh ada di muka bumi.

4. Air zam-zam adalah nikmat terbesar dan memiliki manfaat yang nyata di Bait al-Haram.

5. Air zam-zam adalah air yang muncul perantara Jibril.

6. Air zam-zam adalah air yang digunakan untuk menyucikan shadr Nabi Muhammad SAW.

7. Air zam-zam akan mengenyangkan bagi yang lapar.

8. Air zam-zam adalah penawar segala penyakit.

9. Di dalam air zam-zam terdapat obat pereda demam.

10. Air zam-zam dapat menyehatkan tubuh dan menguatkan badan. (Bakdasy, 2000)

\section{Kristalografi Air Zamzam}

Air zam zam yang merupakan air suci dan istimewa ini memiliki molekul yang indah. Tidak seperti molekul air pada umumnya, molekul air zam zam membentuk kristal yang indah berbentuk heksagonal sempurna dan berkilau, terlebih saat dibacakan ayat Al-Quran atau kata-kata yang baik seperti kata-kata pujian kepada Allah dan Rasul.

Masaru Emoto, Peneleti dari Hado Institute di Tokyo telah melakukan penelitian mengenai molekul molekul air yang bisa berubah-ubah sesuai niat atau perkataan seseorang saat akan meminumnya. Degan berdialog dengan air dengan dialog positif, maka air pun akan memberikan timbal balik positif. (Emoto, 2006) 
Masaru Emoto menyebutkan bahwa molekul air zam zam merupakan bentuk molekul yang sempurna dan teratur. Di Malaysia, Prof. Masaru Emoto menyajikan hasil risetnya yang ia tulis dalam bukunya yang berjudul The True Power of Water. Dalam presentasinya, ia menampilkan gambar beberapa kristal dari beberapa sampel air yang ia teliti. Lalu tampak satu gambar dengan kristal yang sangat indah. Ketika salah satu peserta bertanya air apa yang membentuk kristal indah tersebut, Prof. Masaru Emoto menjawab bahwa kristal indah tersebut dibentuk dari air zam-zam.(Ritongga, 2011)

Baru-baru ini, eksperimen semeiotik biofisik kuantum telah menawarkan bukti baru tentang keberadaan hubungan antara memori air dan informasi penyembuhan, persis mengikuti hipotesis menarik Emoto tentang perubahan kristal air yang dicapai oleh musik dan lagu. Emoto melewatkan frekuensi suara yang berbeda melalui air zamzam dan mengamati perilaku kristal variabel berdasarkan teknik kristalografi antara air zamzam dan sampel air dari belahan dunia lain. Menariknya, dia memperhatikan bahwa air ini memiliki interaksi dan reaksi khusus ketika kata-kata Allah dalam Alquran dibacakan padanya. Emoto meneteskan beberapa tetes air zamzam dan melafalkan "Bismillah" dalam bahasa Arab dan melihat susunan partikel air yang unik dalam bentuknya. Ia mengamati partikel air mengambil bentuk yang berbeda dibandingkan dengan partikel air lain yang diambil dari air di dunia. Emoto tidak dapat mengkristalkan air zamzam bahkan setelah mengencerkan zamzam sebanyak 1000 kali. Namun, dia mendapatkan kristal berbentuk unik setelah dibekukan.

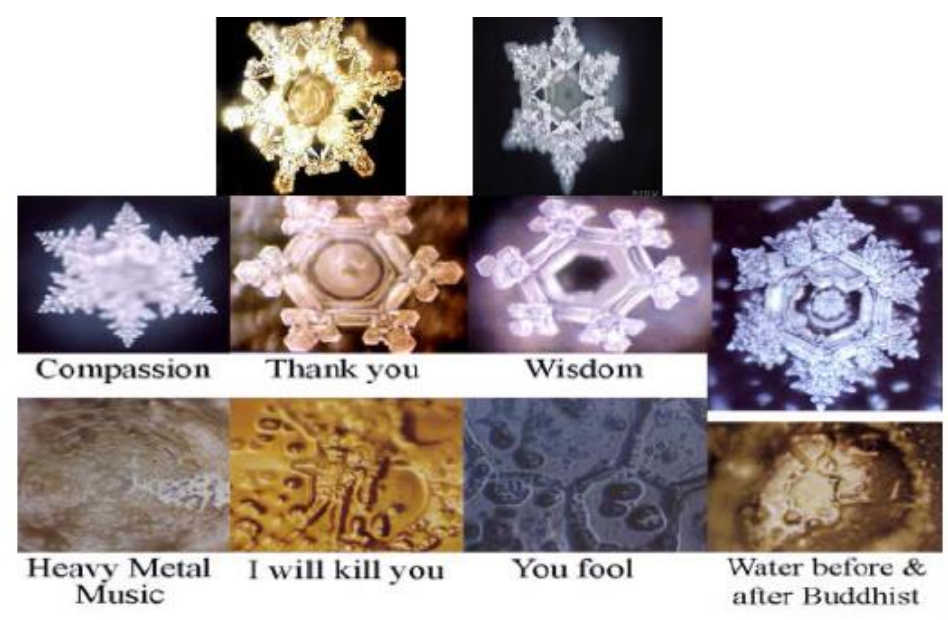




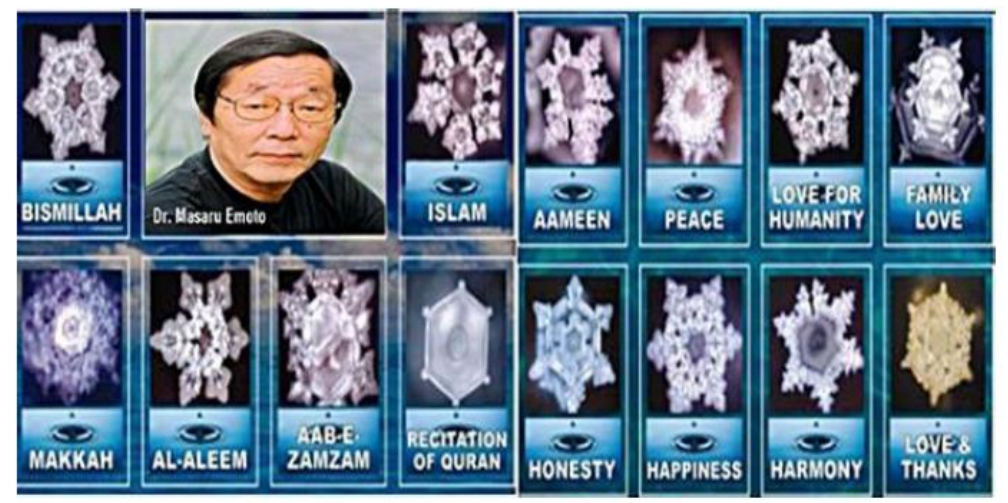

(Emoto, 2006)

\section{Profil anorganik air ZamZam}

Metode progresif studi multi-unsur dan hidro kimia air ZamZam dilakukan oleh banyak peneliti yang bekerja pada induktivitas awal neutron bergabung plasma; dan metode tradisional lain yang tersedia untuk memeriksa sampel air. Metode ini mengekspos 34 unsur dalam air Zam Zam dengan kalsium (Ca), magnesium $(\mathrm{Mg})$, natrium $(\mathrm{Na})$ dan klorida $(\mathrm{Cl})$ dalam konsentrasi yang lebih tinggi daripada air alami. Dan unsur antimon $(\mathrm{Sb})$, berilium $(\mathrm{Be})$, bismut $(\mathrm{Bi})$, brom (Br), kobalt (Co), yodium (I) dan molibdenum (Mo) adalah 23 kurang dari 0,01 ppm. Hanya jejak kromium (Cr), mangan ( $\mathrm{Mn}$ ) dan titanium (Ti) yang terlihat di air Zam Zam. Studi hidro kimiawi air ZamZam menunjukkan bahwa itu adalah air natrium klorida yang berasal dari meteorit. Kuantitas empat unsur berbahaya, arsen (As), kadmium (Cd), timbal $(\mathrm{Pb})$, dan selenium (Se), jauh di bawah tingkat risiko untuk diminum manusia. Banyak ahli menyarankan bahwa individu tertentu membuat air Zam Zam lebih baik, seperti tingkat kalsium yang lebih tinggi. (Nuaman, 2013)

\section{Air Zam zam dan Kanker}

Didalam pedoman diet di seluruh dunia menyarankan untuk meningkatkan konsumsi makanan nabati untuk memerangi penyakit yang tidak dapat disembuhkan seperti kanker, penyakit kardiovaskular, diabetes, dan osteoporosis. Air zamzam secara alami bersifat basa (alkali) dan kaya akan berbagai mineral yang dapat digunakan sebagai terapi kanker, seperti kanker payudara, kolorektal, ovarium, dan paru-paru. Air alkali memiliki aktivitas antioksidan yang kuat dan 
efek antikanker. Manfaat ini melindungi DNA dari kerusakan oksidatif (radikal bebas) dalam tubuh, yang merupakan penyebab utama penuaan dini dan timbulnya penyakit kanker.

Selain itu, konsentrasi ion kalsium dan magnesium dalam air zamzam nyaris dua kali lipat dibandingkan konsentrasi yang ditemukan dalam air mineral kemasan. Kecukupan asupan kalsium ini dapat mengurangi risiko kanker usus dan payudara, sementara magnesium dapat mencegah potensi metastasis (penyebaran) sel kanker. (Rao \& Ali, 2007)

\section{Air Zamzam dan Karies Gigi}

Sebuah penelitian pernah dilakukan oleh Dr Nour Al Zuhair dan Prof Rita Khounganian dari King Saud University untuk membandingkan kandungan mineral air Zam-zam. Sebagai pembandingnya adalah air keran yang ada di Arab Saudi, yang juga sering dikemas dalam botol. Dari hasil penelitian tersebut diketahui bahwa salah satu kelebihan air Zam-zam adalah memiliki kandungan mineral khususnya fluoride yang lebih tinggi. Air Zam-zam yang diambil langsung dari sumbernya memiliki kadar fluoride 0,75 ppm sementara yang dialirkan melalui pipa sebanyak 0,68 ppm. Kadar ini lebih tingi dibandingkan rata-rata kandungan fluoride dalam air keran di Arab Saudi yang hanya sekitar 0,28 ppm. Sementara menurut WHO, tubuh manusia mampu menerima kandungan fluoride dalam air minum hingga kadar 1,5 ppm. Bagi manusia, kadar fluoride yang tinggi dalam air minum bisa memberikan manfaat khususnya untuk menjaga kesehatan gigi dan mulut. Kekurangan fluoride bisa memicu gigi keropos atau dental caries yang jika memburuk bisa memicu infeksi pada gusi. (Dean, Arnold, \& Evolve, 1942)

\section{Air Zamzam dan Stimulasi Sistem Reproduksi}

Zam Zam digunakan dalam manajemen kegagalan implantasi, untuk stimulus prolaktin endometrium, pertahanan $\alpha$ dan $\beta$, luteinizing hormone (LH), faktor pertumbuhan endotel vaskular endometrium (VEGF), dan reseptor angiopoietin. Selain itu, air Zam Zam menyebabkan regulasi pesan antar sel gap junctional dan antibodi connexin 43 di endometrium. Terbaru, Ali et al. 


\section{n}

menunjukkan bahwa air Zam Zam merangsang diferensiasi sel induk di endometrium. Kejadian ini dihasilkan karena kandungan kalsium dan magnesium yang tinggi pada Zamzam. Selain itu, air memberikan lebih banyak dukungan untuk banyak prosedur biokimia lainnya di endometrium, termasuk peran vitalnya sebagai koenzim selama pengembangan imunoglobulin Zam Zam merangsang perkembangan jendela implantasi melalui stimulus AQP karena ia memiliki kandungan fluorida yang tinggi, berkontribusi pada aksi antimikroba yang solid. Air Zam Zam bertindak sebagai antioksidan karena merangsang oksida nitrat endometrium (NO). Ini juga merangsang faktor neurotropik yang diturunkan dari otak endometrium (BDNF). Dinyatakan bahwa air Zam Zam merupakan modalitas baru untuk berulang kali gagal injeksi sperma intracytoplasmic (ICSI). Namun, sejumlah besar penelitian acak ingin menguji keefektifan dari pengobatan baru ini.(El-Zaiat, 2007)

Selain itu, aborsi insufisiensi serviks dapat dikontrol dengan air Zam Zam, karena air Zam Zam mengaktifkan sel autologous human peripheral blood mononuclear (PBM) yang memiliki efek positif pada janin dan tidak memiliki masalah fetomaternal.(Ali, Hassain, \& El Hosani, 2009)

\section{KESIMPULAN}

Berdasarkan fakta-fakta sains diatas, telah terbukti bahwa air zamzam memiliki berbagai macam keistimewaan dan khasiat. Sehingga dapat dikatakan bahwa justifikasi Nabi dalam hadis tentang air zam-zam merupakan sebuah kebenaran yang dapat dibuktikan dengan fakta penelitian modern. 


\section{DAFTAR PUSTAKA}

Ad-Daraqutni, A. i. (2004). Sunan Ad-Daraqut\}ni, Vol 3. Beirut: Muassah alRisalah, 354.

Al-Gamal, S. (2008). Remarks on the isotopic composition of HolyWater of Zamzam, Mecca area. . In World Environment Magazine(we) World Environment Group, 19-22.

Ali, A., Hassain, M., \& El Hosani, A. (2009). Zam Zam water a new modality for failed repeated intra cytoplasmic sperm injection. In: 13th International Water Technology Conference. IWTC: Hurghada, Egypt , 1557-1560.

al-Qazwini, A. A. (1995). Sunan Ibnu Majjah, Vol 2. Beirut: Dar al-Fikr, 214.

Bakdasy, S. (2000). Fadhl Ma’ Zam-zam. Beirut: Dar al-Basyair al-Islamiyah.

Dean, H., Arnold, F., \& Evolve, E. (1942). Domestic water and dental caries, V. Additional studies of the relation of fluoride of domestic water to dental caries experience in 4425 white children aged 12-14 years, of 13 cities in 4 states. Public Health Reports, 1155-1179.

El-Zaiat, S. (2007). Inherent Optical Properties Of Zamzam Water in The Visible Spectrum: Dispersion Analysis. The Arabian Journal For science and Engineering, 171-180.

Emoto, M. (2006). The True Power of Water. . Bandung: MQ Publishing.

Hanbal, A. i. (1995). Musnad Imam Ahmad, Vol 3. Beirut: Mu'assasah alRisala., 357.

Naeem, A. A. (1983). Multielemental and Hydrochemical Study of Holy Zamzam Water. NEWWA, 159- 169.

Nuaman. (2013). Health and Functionality of Zam Zam water .

Ramer, T. (1994). Animal Protein Cause Calcium Leached From The bones. Am J Clin Nut, 59. 
Rao, A. V., \& Ali, A. (2007). Biologically Active Phytochemicals in human health: Lycopene. International Journal Of Food Properties , 279-288.

Ritongga, P. S. (2011). Air Sebagai Sarana Peningkatan Imtaq (Integrasi Kimia dan Agama). Jurnal Sosial Budaya Vol. 8. 